\title{
ANALISIS POTENSI TEKNOLOGI PEMANEN KABUT (FOG HARVESTING) SEBAGAI ALTERNATIF SUMBER DAYA AIR TERBARUKAN DI KABUPATEN TORAJA UTARA (Studi Kasus: Desa Benteng Mamullu, Kecamatan Kapalapitu)
}

\author{
Dian Pranata Putra Ambali ${ }^{1}$, Jumiarti Andi Lolo \\ 1*) Program Studi Teknik Sipil, Fakultas Teknik, Universitas Kristen Indonesia Toraja. \\ 2) Program Pendidikan Fisika, Universitas Kristen Indonesia Toraja, Tana Toraja \\ Jl. Nusantara No. 12,Makale, Tana Toraja, Sulawesi Selatan
}

*dian.pranata.putra@gmail.com

\begin{abstract}
ABSTRAK
Air merupakan sumber daya alam yang vital bagi keberlangsungan hidup manusia bahkan semua makhluk hidup. Namun saat ini, masalah utama yang dihadapi oleh sumber daya air ada dua yaitu kuantitas dan kualitas air. Pada saat musim kemarau, kuantitas air yang tersedia tidak dapat mencukupi kebutuhan air sehingga diperlukan konservasi terhadap sumber daya air alternatif terbarukan untuk pemenuhan kebutuhan air. Kabut memiliki potensi sebagai sumber alternatif air tawar jika dapat dipanen secara maksimal. Pemanen kabut adalah teknologi inovatif berdasarkan fakta bahwa air dapat dikumpulkan dari kabut di bawah kondisi iklim yang menguntungkan. Kabupaten Toraja Utara merupakan dataran tinggi yang memiliki potensi kabut yang dapat dipanen namun belum pernah dilakukan sehingga diperlukan penelitian awal untuk mengetahui seberapa besar potensi air yang dapat dipanen dari kabut. Penelitian ini menggunakan model Standard Fog Collector sebagai alat pemanen kabut. Pemilihan model didasarkan pada kemudahan perakitan alat dan biaya pembuatan serta biaya perawatan yang lebih ekonomis. Alat pemanen kabut yang digunakan berukuran $2 m \times 1 m$ dibuat sebanyak dua buah yang dipasang saling tegak lurus (bentuk L) agar dapat menangkap kabut secara maksimal dari semua arah angin yang nantinya membawa kabut. Penelitian dilakukan dengan mengukur volume air yang dihasilkan setiap harinya dari alat pemanen kabut. Volume air yang diperhitungkan hanya pada hari dimana tidak terjadi hujan sehingga air yang terkumpul pada penampungan merupakan air yang berasal dari kabut saja. Volume air yang dikumpulkan dari alat pemanen kabut selama 3 bulan penelitian pada bulan pertama sebanyak $1.410 \mathrm{ml}$, bulan kedua sebanyak $2.560 \mathrm{ml}$, dan pada bulan ketiga sebanyak $3.750 \mathrm{ml}$. Rata-rata volume air harian yang diperoleh pada bulan pertama sebanyak 54,23 ml, bulan kedua sebanyak 86,45 ml dan pada bulan ketiga sebanyak 117,10 ml. Volume air pada bulan pertama lebih kecil dibandingkan dengan 2 bulan berikutnya. Hal ini dikarenakan pada bulan pertama sering terjadi hujan sehingga volume air yang masuk ke penampungan tidak diperhitungkan. Selain itu, pada bulan pertama intensitas kabut juga tidak sebanyak pada bulan kedua dan ketiga. Berdasarkan data yang diperoleh, volume air yang dikumpulkan relatif sangat sedikit sehingga tidak bisa dimanfaatkan untuk pemenuhan kebutuhan air sehari-hari. Volume air yang dihasilkan dapat dimanfaatkan untuk mensubsidi kebutuhan air tanaman yang tidak terlalu banyak membutuhkan air. Faktor yang paling berpengaruh pada volume air yang dihasilkan adalah luas bidang tangkap kabut dan penempatan alat pemanen kabut.
\end{abstract}

Kata Kunci: air, kabut, konservasi

\section{PENDAHULUAN}

\subsection{Latar Belakang}

Air merupakan sumber daya alam yang vital bagi keberlangsungan hidup manusia bahkan semua makhluk hidup. Oleh karena itu sumber daya air harus dilindungi agar tetap dapat dimanfaatkan dengan baik oleh manusia serta makhluk hidup lainnya. Kebutuhan akan air baik oleh manusia, hewan dan tumbuhan harus selalu dapat dipenuhi. Tidak tersedianya air untuk pemenuhan kebutuhan setiap harinya dapat merusak keseimbangan kehidupan antar makhluk hidup.

Saat ini, masalah utama yang dihadapi oleh sumber daya air ada dua yaitu kuantitas dan kualitas air. Secara kuantitas, 
peningkatan kebutuhan air mengakibatkan terjadi pergeseran imbangan air yaitu perbandingan antara kebutuhan air dengan ketersediaan air. Selain itu kualitas air juga semakin menurun sebagai akibat dari perubahan tata guna lahan yang dapat mencemari sumber-sumber air untuk kebutuhan manusia dan makhluk hidup lainnya.

Sebagian besar masyarakat Toraja Utara khususnya yang bermukim pada daerah pegunungan bekerja sebagai petani dan peternak. Kebutuhan air untuk lahan pertanian dan hewan ternak cukup besar. Sawah di Toraja Utara adalah sawah tadah hujan yaitu sawah yang sistem irigasinya hanya bergantung pada intensitas curah hujan. Saat musim kemarau tiba, kegiatan pertanian ataupun perkebunana berkurang karena jumlah air yang sedikit sedangkan tanaman seperti padi memiliki konsumsi air yang cukup besar.

Penanaman padi pada saat musim kemarau memiliki potensi gagal panen akibat kekurangan air yang cukup besar. Diperlukan konservasi terhadap sumber daya air alternative terbarukan untuk pemenuhan kebutuhan air selama musim kemarau.

Sebagai salah satu kabupaten yang berada di dataran tinggi serta ditunjang dengan kondisi alam yang masih hijau, Toraja Utara memiliki potensi jumlah kabut yang cukup besar. Potensi kabut yang cukup besar ini belum didukung dengan adanya teknologi yang digunakan untuk memanfaatkannya. Di Indonesia sendiri, hanya terdapat beberapa lokasi dataran tinggi yang telah menerapkan teknologi pemanen kabut (fog harvesting) sebagai salah satu solusi permasalahan kekeringan pada dataran tinggi. Penerapan teknologi pemanen kabut pada beberapa daerah di Indonesia digunakan untuk memenuhi kebutuhan air perkebunan. Tetapi penggunaan teknologi pemanen kabut ini tidak bisa serta merta digunakan pada setiap daerah sehingga diperlukan penelitian awal agar penggunaan teknologi ini dapat bekerja secara optimal bila digunakan untuk memenuhi kebutuhan air.

\subsection{Tujuan Penelitian}

Tujuan dari penelitian ini adalah untuk mengetahui efektifitas penggunaan teknologi pemanen kabut di Kabupaten Toraja Utara/

\subsection{Manfaat Penelitian}

Dari hasil penelitian ini diharapkan dapat memberikan solusi alternatif terhadap masalah kekurangan air pada saat musim kemarau untuk memenuhi kebutuhan air.

\section{KAJIAN PUSTAKA}

\subsection{Kabut}

Kabut merupakan tetes-tetes air berbutir kecil yang melayang-layang di udara. Kabut mirip dengan awan tetapi tidak menyentuh permukaan tanah. Kabut secara sederhana terbentuk karena udara yang jenuh akan uap air didinginkan di bawah titik beku. Partikel kabut memiliki diameter lebih kecil dari $0,001 \mathrm{~mm}$. Kabut dapat terbentuk apabila udara didinginkan di bawah titik tertentu (titik embun). Syarat selanjutnya adalah udara yang sejuk tadi bercampur dengan udara yang lebih hangat. Jika aliran udara rendah maka pendinginan terjadi dekat permukaan tanah. Oleh sebab itu kabut seringkali kita lihat di pagi hari karena pada malam hari suhu akan menurun drastis dan ketika menjelang fajar akan menghangat sehingga terbentuklah kabut. Kabut dapat dianggap sebagai jenis awan dataran rendah dan sangat dipengaruhi oleh perairan, topografi, dan kondisi angin di sekitarnya. Kabut terbentuk ketika perbedaan antara suhu udara dengan titik embun kurang 
dari $2,5^{\circ} \mathrm{C}$.

Embun adalah uap air yang mengalami perubahan wujud dari gas menjadi air. Embun terbentuk ketika udara yang dekat dengan permukaan tanah menjadi dingin mendekati titik dimana udara tidak dapat lagi menahan semua uap air. Embun terbentuk dengan baik ketika malam hari yang cerah dan tenang. Ketika angin bertiup, udara tidak cukup waktu untuk bersentuhan dengan benda-benda dingin, sehingga membutuhkan lebih banyak waktu untuk menjadi dingin mendekati titik embun. Ketika langit berawan benda-benda menjadi dingin lebih lama karena awan memancarkan kembali panas ke bumi. Embun juga terbentuk dengan baik ketika kelembaban tinggi.

Kabut dapat terbentuk dalam beberapa cara, tergantung pada bagaimana pendinginan yang menyebabkan kondensasi terjadi. Beberapa jenis kabut berdasarkan proses pembentukannya antara lain:

a. Kabut Radiasi

Kabut Radiasi biasanya terjadi di musim dingin, dibantu oleh langit cerah dan kondisi tenang. Pendinginan tanah semalam oleh radiasi panas mendinginkan udara dekat ke permukaan. Hal ini mengurangi kemampuan udara untuk menahan kelembaban sehingga memungkinkan kondensasi dan kabut terjadi. Kabut radiasi biasanya menghilang segera setelah matahari terbit saat tanah menghangat. Pengecualian untuk ini dapat berada di daerah elevasi tinggi di mana matahari memiliki pengaruh kecil dalam pemanasan permukaan.

b. Kabut Lembah

Kabut lembah terbentuk di mana udara padat yang dingin mengendap di bagian bawah lembah kondensing dan membentuk kabut. Seringkali hasil dari inversi suhu dengan udara hangat yang lewat di atas lembah. Kabut lembah dibatasi oleh topografi lokal dan dapat berlangsung selama beberapa hari dalam kondisi tenang selama musim dingin.

c. Kabut Adveksi

Kabut adveksi terjadi ketika udara lembap melewati permukaan yang dingin dan didinginkan. Contoh umum dari kabut ini adalah ketika bagian depan yang hangat melewati area dengan penutup salju. Hal ini juga umumnya terjadi di laut ketika udara tropis yang lembab bergerak di atas perairan yang lebih dingin. Jika angin bertiup ke arah yang benar maka kabut laut dapat terangkut di atas daratan pantai

d. Kabut Lereng

Kabut lereng atau dataran tinggi terbentuk ketika angin meniupkan udara ke atas lereng (disebut orographic uplift). Udara mendingin saat naik, memungkinkan kelembaban di dalamnya mengembun.

e. Kabut Evaporasi

Kabut evaporasi disebabkan oleh udara dingin yang melewati air hangat atau lahan basah. Sering menyebabkan kabut beku, atau kadang-kadang beku. Ketika sebagian dari air yang relatif hangat menguap ke lapisan udara rendah, ia menghangatkan udara yang menyebabkannya naik dan bercampur dengan udara dingin yang telah melewati permukaan. Udara yang hangat dan lembab mendingin karena bercampur dengan udara yang lebih dingin, memungkinkan terjadinya kondensasi dan kabut.

\subsection{Teknologi Pemanen Kabut}

Kabut memiliki potensi untuk menyediakan sumber alternatif air tawar serta berkelanjutan di daerah kering dan dapat dipanen melalui penggunaan sistem pengumpulan sederhana dan murah [1]. Kabut juga merupakan sumber alternatif yang terbarukan karena mengikuti siklus hidrologi. Secara fisis, kualitas air yang dihasilkan dari kabut juga cukup baik. Hal ini dapat dilihat dari pengamatan langsung bahwa air yang 
dihasilkan dari kabut tidak berwarna ataupun berbau. Walaupun kemudian diperlukan penelitian tentang kualitas air dengan berbagai indikator yang tidak bisa diamati langsung tetapi harus melalui pengujian di laboratorium. Air yang diambil kemudian dapat digunakan untuk pemenuhan kebutuhan air sehari-hari atau untuk pertanian. Kabut juga bisa dipanen di daerah pantai di mana kabut bergerak ke daratan yang digerakkan oleh angin. Air dalam kabut dipanen melalui sistem sederhana yang dikenal sebagai fog collector.

Pemanen kabut adalah teknologi inovatif berdasarkan fakta bahwa air dapat dikumpulkan dari kabut di bawah kondisi iklim yang menguntungkan. Tetesan air kecil yang ada di kabut mengendap ketika mereka bersentuhan dengan objek. Kabut memiliki potensi untuk menyediakan sumber alternatif air tawar jika dipanen melalui penggunaan sistem pengumpulan sederhana dan murah yang dikenal sebagai fog collector. Penggunaan pemanen kabut dengan model standard fog collector dapat menghasilkan air sebanyak 8 liter untuk tiap meter persegi jaring dengan kecepatan angin antara $3 \mathrm{~m} / \mathrm{s}$ sampai $12 \mathrm{~m} / \mathrm{s}$ [2]. Namun data tersebut tidak bisa dijadikan standar atau dapat sesuai di setiap daerah berkabut karena ada juga penelitian yang memperoleh data bahwa untuk setiap meter persegi jaring adalah sebanyak 879,9 liter air [3]. Selain faktor elevasi lokasi penelitian, faktor material penagkap kabut baik itu berupa kerapatan dari jaring serta kemampuan material untuk mengalirkan air dengan cepat juga mempengaruhi hasil yang diperoleh [4][6].

\subsection{Standar Fog Collector}

Standard fog collector merupakan salah satu jenis pemanen kabut yang terbuat dari jaring polipropilen. Jaring tersebut dibentangkan dengan posisi tegak lurus terhadap arah angin kemudian di bagian bawah dipasang saluran untuk mengalirkan air yang terperangkap menuju reservoir. Prinsip kerja standard fog collector adalah alat ini menangkap butiranbutiran air yang terkandung dalam kabut kemudian air yang terperangkap di jaring akan bergerak ke bawah mengikuti gravitasi dan mengalirkan air tersebut sebuah reservoir yang sudah disiapkan [5].

Beberapa kelebihan penggunaan teknologi pemanen kabut antara lain:

- Biaya yang rendah

- Teknologi dan penerapan sederhana

- Airnya berkualitas baik

- Tidak terpengaruh musim kemarau

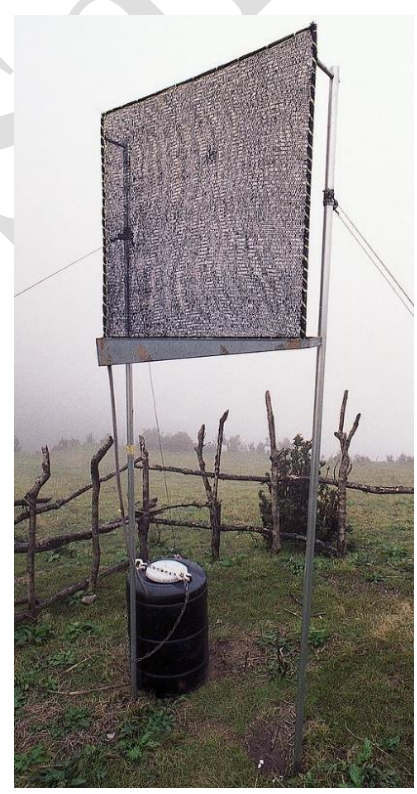

Gambar 2.1. Standard Fog Collector

\section{METODOLOGI PENELITIAN}

\subsection{Lokasi dan Waktu Penelitian}

Penelitian dilakukan pada objek wisata Tiro Tiku (Lolai), Kecamatan Kapala Pitu, Kabupaten Toraja Utara dengan memilih salah satu titik pada ketinggian lebih besar dari 1200 mdpl dan mempunyai intensitas kabut yang cukup. Penilitan dilakukan selama 3 bulan yaitu pada bulan Juni, Juli dan Agustus. 


\subsection{Model Alat Penelitian}

Model yang digunakan dalam penelitian ini untuk memanen kabut adalah Standard Fog Collector. Alat ini terdiri dari jaring paranet dengan ukuran luas $2 \mathrm{~m} 2$ (panjang $2 \mathrm{~m}$ dan lebar $1 \mathrm{~m}$ ). Jaring dipasang pada bingkai yang terbuat dari bambu/ kayu kemudian posisi jaring ditempatkan sekitar 2 meter di atas permukaan tanah. Di bagian bawah jaring dipasang sebuah talang pengumpul air yang jatuh dari jarring kemudian diarahkan menuju sebuah bak penampungan/reservoir. Talang dipasang dengan kemiringan tertentu sehingga air dapat mengalir dengan baik menuju penampungan. Instalasi pemanen kabut ini dipasang dua buah dengan posisi tegak lurus (Gambar 3.1.). Hal ini dilakukan untuk mengantisipasi arah angin yang bisa saja berubah-ubah. Dengan instalasi demikian maka pemanen kabut dapat menangkap kabut dari berbagai arah angin [2].

Data yang diharapkan dapat diperoleh pada penelitian ini adalah volume air yang dihasilkan tiap hari pada saat tidak terjadi hujan sehingga air yang terkumpul adalah hasil dari pemanen kabut bukan air hujan. Apabila terjadi hujan maka jumlah air yang terkumpul di dalam reservoir tidak termasuk dalam data.

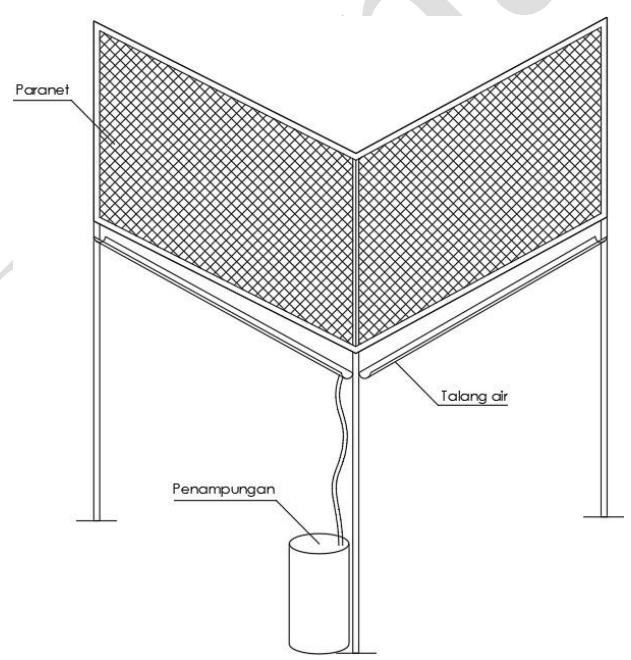

Gambar 3.1. Model alat penelitian

\subsection{Tahapan Penelitian}

1. Mengumpulkan Informasi Lokasi Penelitian Pada tahapan ini, peneliti menumpulkan informasi mengenai lokasi penelitian melalui survey pendahuluan serta wawancara dengan penduduk sekitar. Informasi yang sangat dibutuhkan pada tahapan ini adalah tentang intensitas kabut pada lokasi penelitian serta kondisi cuaca lainnya seperti suhu, arah dan kecepatan angin serta curah hujan. Melalui infomasi ini dapat ditentukan lokasi yang tepat untuk penelitian.

2. Instalasi Alat Setelah titik lokasi penelitian ditentukan, kemudian alat dan bahan dimobilisasi ke lokasi penelitian untuk kemudian dipasang sesuai dengan desain yang direncanakan. Setelah alat terpasang, dilakukan uji coba terhadap alat penelitian agar berfungsi sesuai rencana sehingga tidak ada faktor-faktor lain yang dapat mempengaruhi data.

3. Pengamatan Setelah alat penelitian telah berfungsi sebagaimana mestinya, kemudian pengamatan mulai dilakukan dengan mencatat setiap data yang dibutuhkan dalam analisis nantinya. Pegamatan dilakukan selama kurang lebih 3 bulan pada musim kemarau/ kering. Adapun jika terjadi hujan, maka data pada hari tersebut tidak dimasukkan dalam inventarisasi data. Semua faktor yang mempengaruhi hasil pengamatan selama penelitian juga dicatat sebagai bahan analisis pada tahapan berikutnya.

4. Analisis Data Data yang terkumpul kemudian dianalisis untuk mendapatkan tujuan dari penelitian ini. Data yang ada disajikan dalam bentuk tabel dan diagram dengan interval waktu tertentu. Kemudian disusun sebuah kesimpulan yang dapat diperoleh dari penelitian ini. 


\section{HASIL DAN PEMBAHASAN}

\subsection{Kompilasi Data}

Dalam penelitian ini data yang diperoleh berupa data volume air harian yang diukur dari penampungan setiap harinya kecuali pada saat terjadi hujan. Karena sistem yang digunakan berupa saluran terbuka sehingga pada saat hari hujan, air akan masuk ke talang dan terkumpul ke dalam penampungan bersamaan dengan air yang dihasilkan dari kabut. Data pada saat hari hujan diabaikan karena pada penelitian ini berfokus untuk mengetahui volume air yang dihasilkan dari alat pemanen kabut.

Data volume air harian tiap bulan yang diperoleh disajikan pada Tabel 1., Tabel 2., dan Tabel 3.

Tabel 1 : Data Volume Air Harian Bulan Juni

\begin{tabular}{|c|c|c|c|}
\hline No & Tanggal & $\begin{array}{l}\text { Volume } \\
\text { Air (ml) }\end{array}$ & $\begin{array}{c}\text { Intensitas } \\
\text { Kabut }\end{array}$ \\
\hline 1 & $05 / 06 / 2019$ & 100 & tipis \\
\hline 2 & 06/06/2019 & 0 & hujan \\
\hline 3 & 07/06/2019 & 0 & hujan \\
\hline 4 & 08/06/2019 & 120 & tipis \\
\hline 5 & 09/06/2019 & 100 & tipis \\
\hline 6 & $10 / 06 / 2019$ & 8 & tipis \\
\hline & & 0 & \\
\hline 7 & $11 / 06 / 2019$ & 110 & tipis \\
\hline 8 & $12 / 06 / 2019$ & 0 & hujan \\
\hline 9 & $13 / 06 / 2019$ & 0 & hujan \\
\hline 10 & $14 / 06 / 2019$ & 130 & tipis \\
\hline 11 & $15 / 06 / 2019$ & 0 & hujan \\
\hline 12 & $16 / 06 / 2019$ & 120 & tipis \\
\hline 13 & $17 / 06 / 2019$ & 120 & tipis \\
\hline 14 & $18 / 06 / 2019$ & 110 & tipis \\
\hline 15 & $19 / 06 / 2019$ & 0 & hujan \\
\hline 16 & 20/06/2019 & 80 & tipis \\
\hline 17 & $21 / 06 / 2019$ & 0 & hujan \\
\hline 18 & $22 / 06 / 2019$ & 0 & hujan \\
\hline 19 & 23/06/2019 & 90 & tipis \\
\hline 20 & $24 / 06 / 2019$ & 70 & tipis \\
\hline 21 & $25 / 06 / 2019$ & 0 & hujan \\
\hline 22 & $26 / 06 / 2019$ & 0 & hujan \\
\hline 23 & 27/06/2019 & 0 & hujan \\
\hline 24 & 28/06/2019 & 0 & hujan \\
\hline 25 & 29/06/2019 & 80 & tipis \\
\hline
\end{tabular}

\begin{tabular}{|c|c|c|c|}
26 & $30 / 06 / 2019$ & 100 & tipis \\
\hline Jumlah & 1.410 & \\
\hline
\end{tabular}

Volume air rata-rata yang diperoleh pada bulan Juni sebesar 50,36 ml. Volume air yang diperoleh relatif sangat sedikit karena cukup banyak hari hujan yang terjadi pada bulan Juni sehingga datanya dianggap tidak ada. Dari 26 hari penelitian pada bulan Juni, terdapat 12 hari hujan. Volume air terbesar pada bulan juni adalah $130 \mathrm{ml}$ dan volume terkecil adalah $70 \mathrm{ml}$.

Tabel 2. Data Volume Air Harian Bulan Juli

\begin{tabular}{|c|c|c|c|}
\hline No. & Tanggal & $\begin{array}{l}\text { Volume } \\
\text { air (ml) }\end{array}$ & $\begin{array}{c}\text { Intensitas } \\
\text { kabut }\end{array}$ \\
\hline 1 & $01 / 07 / 2019$ & 0 & hujan \\
\hline 2 & 02/07/2019 & 0 & hujan \\
\hline 3 & 03/07/2019 & 0 & hujan \\
\hline 4 & 04/07/2019 & 70 & tipis \\
\hline 5 & 05/07/2019 & 100 & tipis \\
\hline 6 & 06/07/2019 & 0 & hujan \\
\hline 7 & 07/07/2019 & 180 & tebal \\
\hline 8 & 08/07/2019 & 100 & tipis \\
\hline 9 & 09/07/2019 & 90 & tipis \\
\hline 10 & $10 / 07 / 2019$ & 150 & tebal \\
\hline 11 & 11/07/2019 & 0 & hujan \\
\hline 12 & $12 / 07 / 2019$ & 80 & tipis \\
\hline 13 & 13/07/2019 & 80 & tipis \\
\hline 14 & $14 / 07 / 2019$ & 90 & tipis \\
\hline 15 & 15/07/2019 & 0 & hujan \\
\hline 16 & 16/07/2019 & 180 & tebal \\
\hline 17 & 17/07/2019 & 100 & tipis \\
\hline 18 & 18/07/2019 & 90 & tipis \\
\hline 19 & 19/07/2019 & 110 & tipis \\
\hline 20 & 20/07/2019 & 0 & hujan \\
\hline 21 & 21/07/2019 & 100 & tipis \\
\hline 22 & $22 / 07 / 2019$ & 90 & tipis \\
\hline 23 & 23/07/2019 & 190 & tebal \\
\hline 24 & $24 / 07 / 2019$ & 130 & tipis \\
\hline 25 & 25/07/2019 & 200 & tebal \\
\hline 26 & 26/07/2019 & 100 & tipis \\
\hline 27 & 27/07/2019 & 100 & tipis \\
\hline 28 & 28/07/2019 & 110 & tipis \\
\hline 29 & 29/07/2019 & 0 & hujan \\
\hline 30 & $30 / 07 / 2019$ & 120 & tipis \\
\hline 31 & $31 / 07 / 2019$ & 120 & tipis \\
\hline \multicolumn{2}{|r|}{ Jumlah } & 2.680 & \\
\hline
\end{tabular}


Volume air rata-rata yang diperoleh pada bulan Juli sebesar 86,45 ml. Pada bulan Juli jumlah hari hujan sebanyak 8 hari sehingga dari 31 hari penelitian, 8 data dianggap tidak ada. Volume air terbesar pada bulan juni adalah $200 \mathrm{ml}$ dan volume terkecil adalah $70 \mathrm{ml}$.

Tabel 4.3. Data Volume Air Harian Bulan Agustus

\begin{tabular}{|c|c|c|c|}
\hline $\begin{array}{c}\text { No } \\
\cdot\end{array}$ & Tanggal & $\begin{array}{c}\text { Volume } \\
\text { air }(\mathbf{m l})\end{array}$ & $\begin{array}{c}\text { Intensitas } \\
\text { kabut }\end{array}$ \\
\hline 1 & $01 / 08 / 2019$ & 210 & tebal \\
\hline 2 & $02 / 08 / 2019$ & 190 & tebal \\
\hline 3 & $03 / 08 / 2019$ & 120 & tipis \\
\hline 4 & $04 / 08 / 2019$ & 110 & tipis \\
\hline 5 & $05 / 08 / 2019$ & 110 & tipis \\
\hline 6 & $06 / 08 / 2019$ & 90 & tipis \\
\hline 7 & $07 / 08 / 2019$ & 0 & hujan \\
\hline 8 & $08 / 08 / 2019$ & 100 & tipis \\
\hline 9 & $09 / 08 / 2019$ & 90 & tipis \\
\hline 10 & $10 / 08 / 2019$ & 220 & tebal \\
\hline 11 & $11 / 08 / 2019$ & 100 & tipis \\
\hline 12 & $12 / 08 / 2019$ & 280 & tebal \\
\hline 13 & $13 / 08 / 2019$ & 80 & tipis \\
\hline 14 & $14 / 08 / 2019$ & 170 & tebal \\
\hline 15 & $15 / 08 / 2019$ & 100 & tipis \\
\hline 16 & $16 / 08 / 2019$ & 80 & tipis \\
\hline 17 & $17 / 08 / 2019$ & 180 & tebal \\
\hline 18 & $18 / 08 / 2019$ & 110 & tipis \\
\hline 19 & $19 / 08 / 2019$ & 0 & hujan \\
\hline 20 & $20 / 08 / 2019$ & 0 & hujan \\
\hline 21 & $21 / 08 / 2019$ & 100 & tipis \\
\hline 22 & $22 / 08 / 2019$ & 180 & tebal \\
\hline 23 & $23 / 08 / 2019$ & 180 & tebal \\
\hline 24 & $24 / 08 / 2019$ & 90 & tipis \\
\hline 25 & $25 / 08 / 2019$ & 90 & tipis \\
\hline 26 & $26 / 08 / 2019$ & 100 & tipis \\
\hline 27 & $27 / 08 / 2019$ & 120 & tipis \\
\hline 28 & $28 / 08 / 2019$ & 70 & tipis \\
\hline 29 & $29 / 08 / 2019$ & 170 & tebal \\
\hline 30 & $30 / 08 / 2019$ & 100 & tipis \\
\hline 31 & $31 / 08 / 2019$ & 90 & tipis \\
\hline & Jumlah & 3.630 & \\
\hline
\end{tabular}

Volume air yang diperoleh pada bulan Agustus merupakan yang terbesar dibandingkan dengan dua bulan sebelumnya. Dari 31 hari penelitian, hanya terjadi 3 hari hujan. Volume air rata-rata yang diperoleh pada bulan Agustus sebesar 117,10 ml. Volume air terbesar pada bulan Agustus adalah $280 \mathrm{ml}$ dan volume terkecil adalah 70 $\mathrm{ml}$.

Dari data volume air harian yang diperoleh kemudian dikelompokkan ke dalam data mingguan seperti disajikan pada Tabel 4. dan Gambar 4.1.

Tabel 4. Data Volume Air Mingguan

\begin{tabular}{|c|c|}
\hline Minggu Penelitian & Volume Air (ml) \\
\hline Minggu 1 & 510 \\
\hline Minggu 2 & 480 \\
\hline Minggu 3 & 240 \\
\hline Minggu 4 & 180 \\
\hline Minggu 5 & 540 \\
\hline Minggu 6 & 580 \\
\hline Minggu 7 & 680 \\
\hline Minggu 8 & 760 \\
\hline Minggu 9 & 950 \\
\hline Minggu 10 & 870 \\
\hline Minggu 11 & 640 \\
\hline Minggu 12 & 860 \\
\hline Minggu 13 & 430 \\
\hline
\end{tabular}

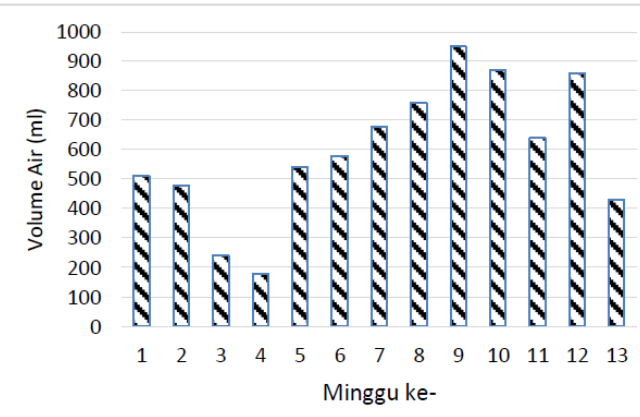

Gambar 4.1. Grafik volume air mingguan

Data volume air mingguan menunjukkan bahwa volume air yang terbesar adalah pada minggu ke- 9 sebanyak $950 \mathrm{ml}$ dan yang terkecil pada minggu ke-4 sebanyak $180 \mathrm{ml}$. Volume air yang sedikit diakibatkan 
karena adanya hari hujan pada minggu tersebut sehingga datanya diabaikan selain itu intensitas kabut juga tipis. Sedangkan volume air yang besar diperoleh karena jumlah hari hujan yang sedikit ataupun tidak ada pas minggu tersebut dan juga intensitas kabut tebal terjadi beberapa kali.

\subsection{Pembahasan}

Data hasil penelitian menunjukkan bahwa terdapat ketimpangan data baik harian, mingguan serta bulanan. Hal ini disebabkan beberapa faktor yang mempengaruhi volume air yang dihasilkan dari alat pemanen kabut. Faktor-faktor yang mempengaruhi volume air yang diperoleh dari alat pemanen kabut antara lain:

a. Luas bidang tangkap

Penelitian ini menggunakan alat pemanen kabut dengan luas bidang tangkap $4 \mathrm{~m}^{2}\left(2 \times 2 \mathrm{~m}^{2}\right)$. Dengan luasan tersebut, alat pemanen kabut hanya mampu menghasilkan air rata-rata $87,73 \mathrm{ml} /$ hari. Semakin luas bidang tangkap, volume air dari kabut yang dihasilkan juga akan semakin banyak.

b. Penempatan alat

Alat pemanen kabut harus ditempatkan pada elevasi yang sesuai dimana potensi intensitas kabut cukup besar. Selain itu, sebaiknya juga ditinjau arah angin dominan pada lokasi penempatan alat agar diperoleh hasil yang maksimal.

c. Vegetasi di lokasi penempatan alat Penempatan alat harus memperhatikan kondisi lingkungan sekitar. Alat yang dipasang sebaiknya tidak terhalang pohon ataupun vegetasi lainnya sehingga kabut nantinya tidak tertangkap oleh alat pemanen kabut melainkan tertahan di pohon ataupun tumbuhan lainnya. Sebaiknya juga jarring pengankap kabut diletakkan cukup tinggi dari permukaan tanah sehingga dapat berfungsi maksimal.

\section{d. Cuaca}

Semakin tebal kabut yang terjadi di lokasi penempatan alat pemanen kabut maka potensi untuk menghasilkan air cukup besar. Namun demikian tebal tipisnya kabut tidak bias dipastikan kapan terjadi karena factor cuaca yang juga sulit untuk diprediksi.

Volume air yang dihasilkan dari alat pemanen kabut selama penelitan relatif kecil. Dengan volume tersebut, air yang dihasilkan belum mampu memenuhi kebutuhan air sehari-hari bahlan untuk kebutuhan air tanaman. Namun demikian jika jumlah air yang diperoleh tiap harinya konsisten, air tersebut dapat dimanfaatkan untuk mensubsidi pemenuhan kebutuhan air tanaman yang tidak banyak membutuhkan air. Air yang dihasilkan dari alat pemanen kabut dapat digunakan pada sistem irigasi tetes yang mengalirkan air langsung ke akar tanaman secara perlahan.

\section{KESIMPULAN DAN SARAN}

\subsection{Kesimpulan}

Adapun kesimpulan dari penelitian adalah sebagai berikut :

1. Volume air rata-rata harian yang diperoleh dari alat pemanen kabut dengan luas bidang tangkap $4 \mathrm{~m}^{2}(2 \times 2$ $\mathrm{m}^{2}$ ) selama 3 bulan penelitian adalah $87,73 \mathrm{ml} / \mathrm{hari}$.

2. Faktor-faktor yang mempengaruhi volume air yang dihasilkan alat pemanen kabut antara lain; luas bidang tangkap, penempatan alat, jumlah vegetasi di lokasi penempatan latan dan cuaca.

3. Penggunaan alat pemanen kabut di Kabupaten Toraja Utara cukup potensial namun masih diperlukan penelitian lanjutan untuk mendapatkan hasil yang 
maksimal sehingga air yang diperoleh dapat dimanfaatkan baik untuk pemenuhan kebutuhan air sehari-hari atau hanya sekedar untuk kebutuhan tanaman.

\subsection{Saran}

Diperlukan beberapa penelitian lanjutan seperti pengaruh luas bidang tangkap dan elevasi lokasi penempatan alat pemanen kabut yang sesuai di masing-masing daerah sehingga air yang dihasilkan lebih banyak untuk pemenuhan kebutuhan air.

\section{DAFTAR PUSTAKA}

1. Jeremy, K. et al., 2013, "Fog Water as an Alternative and Sustainable Water Resource", Journal Clean Technology and Environmetal Policy.

2. Risky, A. et al., 2013, "Potensi Teknologi Pemanen Kabut Di Dataran Tinggi Ngoho", Konferensi Teknik Sipil (KonTekS 7).

3. Marzol, M.V., 2002, "Fog Water Collecting in a Rural Park in the Canary Island (Spain)". Atmospheric Reasearch. $87: 352-361$

4. Maula, N., 2017, "Pengaruh Kerapatan Paranet Terhadap Produktivitas Alat Penangkap Kabut Di Dusun Nglurah Wonodadi Kulon Kab. Pacitan", Mekanika: Jurnal Teknik Mesin, Universitas 17 Agustus 1945, Surabaya.

5. Otto, K. et al., 2012, "Fog as a FreshWater Resource: Overview and Perpectives", AMBIO Journal.

6. Kyoo Chul, P., 2013, "Optimal Design of Permeable Fiber Network Structures for FogHarvesting”, ACS Publications 